\title{
TOPICS
}

\section{「打ぶいひも」症候 群*}

\author{
小佐 野満**
}

Key words : OBUIHIMO, cyanosis, venous obstruction, cephalic vein, basilic vein.

乳幼児をへこ帯，あるいは幅広い紐などでお ぶうことは昔からの習慣としてわが国では広く 行われている.

家事と育児に追われる家庭の主婦にとっては， 両手を自由に使らことのできるこのおぶう習慣 は誠に賢い生活の智恵ともいえるものである.

このおぶうことにより上肢にチアノーゼをき たすものが時折みられ，その原因が先天性の静 脈奇形によることが明らかとなった。

通常は上肢の色調はまったく正常で, もちろ ん運動障害などの症状もないが，「おぶ゙いひも」 を腋窩にかけておぶっていると, 次第に上肢に チアノーゼが出現し, 知らずに長時間を経過す ると患側上肢は暗紫色に腫脹して, 一過性の運 動障害をきたすこともある.

またこのような循環障害をくり返していると 患側の手, 前腕は健側に比して太くなる傾向が みられる。

このように「おぶいひも」をかけておぶらこ とにより, 典型的なチアノーゼなどの循環障害 の症状を示すところから, われわれはこれを 「おぶいひも」症候群とよんでいる1) 3).

\section{I . チアノーゼの発現機序}

上肢の静脈系は図 1 のごとく, 前腕からの還 流静脈血は上腕では頭静脈 (V. cephalica) と 貴要静脈 (V. basilica) を流れ，その間には種 々の吻合がある. また深部の上腕静脈 (V. br-

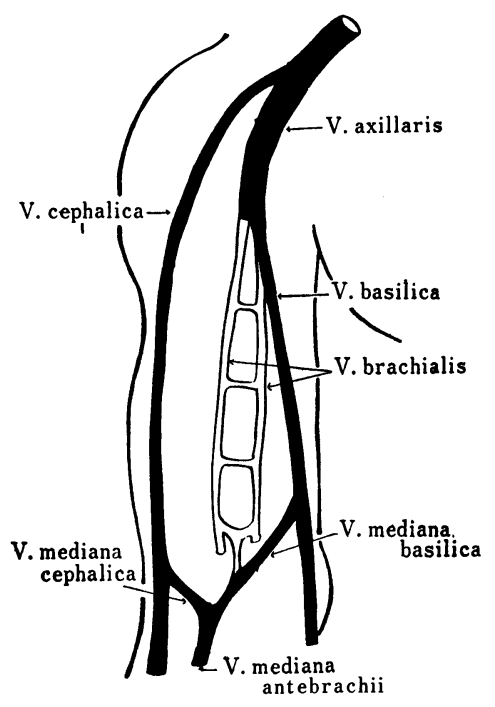

図1

achialis）は貴要静脈に流入している.

貴要静脈は腋窝に達すると腋窩静脈 (V. axillaris）となり，腋窩を越えた後に頭静脈が流 入する.

したがって上腕の静脈系が正常の場 合は, 「おぶいひも」によって腋窩を圧迫し, 腋窩静 脈の還流が妨げられても, 未梢からの還流静脈 血は頭静脈を流れるので, 静脈還流障害は起ら ず，チアノーゼもきたさない.

しかしながら, 先天性に頭静脈が欠除してい る場合は, 上肢の還流静脈血はすべて貴要静脈 より腋窝静脈を流れることになる.したがって

* "OBUIHIMO" syndrome.

** 慶応義塾大学医学部小児科, Mitsuru OSANO : Department of Pediatrics, School of Medicine, Keio Unversity, Tokyo, Japan. 
表 1

\begin{tabular}{|c|c|c|c|c|}
\hline & & 男 & 女 & 計 \\
\hline 右 & 側 & 7 & 5 & 12 \\
\hline 左 & 側 & 2 & 4 & 6 \\
\hline 両 & 側 & 1 & 2 & 3 \\
\hline \multicolumn{2}{|c|}{ 計 } & 10 & 11 & 21 \\
\hline
\end{tabular}

腋嗝に圧迫の加わらない通常の生活ではまった く無症状であるが，腋窩に「抒ぶいひも」をか けておぶうと, 腋窩静脈注圧迫されて通過障害 をきたし，末梢側に静脈性のうっ血を生じ，患 側上肢は暗紫色, かつ浮尰様に腫脹し, 時には 一過性の運動障害をきたすこともある.したが って本症は先天性の頭静脈欠損がその原因であ る.

\section{II. 発生}

静脈系は動脈系と同様に血管芽細胞に由来 し，動脈系によって運ばれた血液を還流させる ベく形成される6).

上肢末梢よりの静脈血を還流させる上腕の静 脈は, 頭静脈と貴要静脈であるが, 発生途上に おいて頭静脈はその重要性を減じるのに反し, 貴要静脈はその発育をつづけ, やがて通常の静 脈系の形が完成される4).

Lewis はウサギの発生学から類推して, 一次 的の上肢の静脈は尺骨側に発生するもので ( V. basilica), 撓骨側(V. cephalica) はそれに附随 するものとしている5).

いゔれにしても上腕の主たる静脈還流は尺骨 側の貴要静脈によるものであり, 他の静脈はこ れに流入しているものと考えられている778).

わが国の成人における上肢の静脈走行異常に ついての詳細な記載をみても，尺骨側の静脈に はほとんど異常はみられない.

これに反し, 撓骨側の静脈には走行異常のか なり多いことがあげられており, 発生学上の所 見を領かせるものである.

また撓骨側の静脈走行異常の中には，上腕に おける静脈欠損の記載もみられるが，特に臨床 上の注意は向けられていない9) 11).
メルボルンの Berry らの報告にも上腕の頭 静脈欠損の記載がある8 ${ }^{8)}$. しかし欧米諸国では 乳幼児をおぶう習慣がなかったために, 腋窝静 脈を圧迫してうっ血をきたす要因の加わる機会 もなく，臨床上の問題ともならずに見逃されて いたものと思われる.

\section{III. 症状}

症状の発現はおぶうことによってはじめて気 付くものであるから, 発見される年齢は, 首が すわり，、わゆる「おんぶ」のできる生後 3 〜 4 カ月以後が通例である。

「おぶいひも」を背中から腋裔にかけておぶ うと, 乳児の体重を支えるために腋䆚にはかな りの圧迫が加わるものである.

時間の経過とともに体重による腋䆚静脈への 圧迫は次第に増強され, 静脈還流障害は著明と なり，通常おぶってから5 分ないし10分のうち に患側上肢は著明なチアノーゼを呈する.

特に患側に傾くようなおぶい方になると，体 重による患側の腋窝静脈への圧迫は一層強くな り, チアノーゼも増強する. したがって, 母親 はつとめてそのような体位にならぬようなおお゙ い方をしている場合が多い。

背中におぶっているために，はじめは上肢の チアノーゼの出現に気付かずに長時間を経過す ることがしばしばある. 30分もそのままにおぶ っていると, 患側の手は暗紫色に腫脹して母親 を驚かせるものである.

またこのような著明な循環障害が長く続いた 時は，「おぶいひも」を外しても一過性の運動 障害をきたし, しばらくの間, 患側上肢を動か さないことがしばしばみとめられる.

本症の本態は静脈還流障害によるうっ血であ るから，腋窩静脈を圧迫している「おぶいひも」 を外せば静脈還流は正常となり，チアノーゼは 急速に消失し, 患側上肢の腫脹も次第に正常に 復するものである.

しかし患側の手, 腕などが暗紫色に腫脹する ほどの循環障害を月余にわたってくり返してい ると, やがて患側の手, 腕などは健側に比して 肥大してくる. 
Blood \& Vessel 1975-6

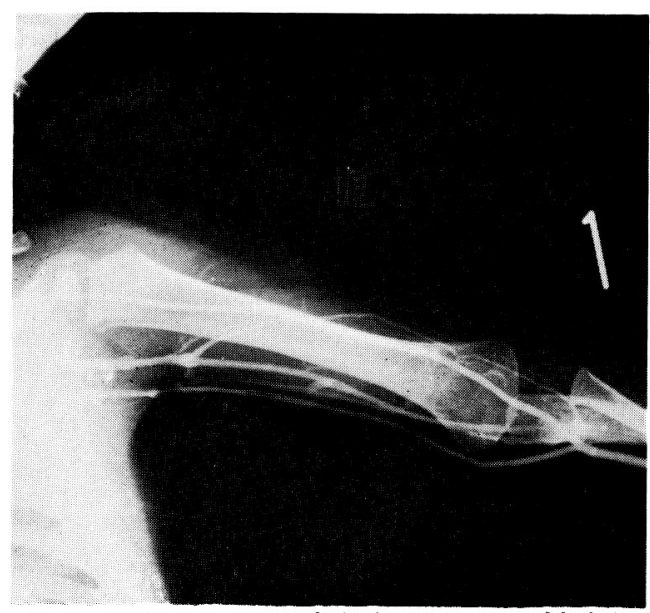

図 2 症例：おぶらと右上肢にチアノーゼをきた す 6 力月の男児. 左側は上腕静脈の走行異 常はあるが頭静脈, 貴要静脈ともに正常.

現在まで 9 年間にわれわれが経験した症例は 21例である。

四肢の静脈系の先天性発育不全は女性に多い といわれているが12)，本症に関しては現在まで のところ，男女比は相半ばしている（表1）.

患側の左右別では右側 12 例, 左側 6 例と明ら かに右側が多い，また21例中 3 例は両側性であ る.

\section{IV. 晾断}

皮下静脈の奇形の存在をみるには，駆血帯に よって上腕上部を圧迫し，怒張する末梢側の皮 下静脈の有無，あるいは走行異常をみる方法が ある9). しかしその信頼性には種々の問題があ り，特に皮下脂肪の多い女性には不適当とされ ている.

乳児は皮下脂肪が多く, かつ, 静脈自体も細 いのでこの方法は用いがたい.

本症が疑われる場合は，まゔ「おぶいひも」 を腋窝にかけ, 両側の腋窝静脈に圧迫の加わる 体位をとらせる。

頭静脈久損であれば久損側は腋窝静脈の圧迫 により静脈血のらっ滞を生じ, 数分の中にチア ノーゼが出現し，やがて左右上肢の色調に著明 な差を認めるにいたる。

確定診断には静脈造影が必要である.われわ れは肘窩部の正中静脈よりポリエチレンチュー

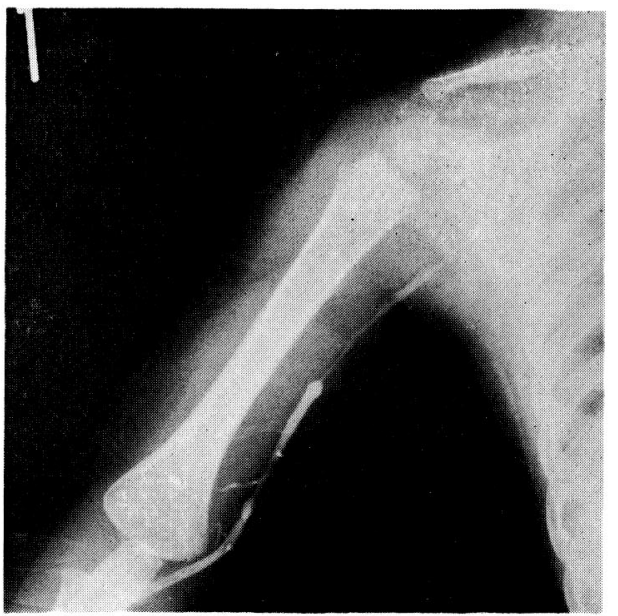

図3 (同一症例) 右側は頭静脈は造影されず， 貴要静脈のみが造影されている.

ブを末梢側に向って $3 \sim 4 \mathrm{~cm}$ 挿入し, 血管とと もに結禁固定したのち，造影剤を $2 \sim 3 m \ell$ 注入 して静脈造影を行っている。

ポリエチレンチューブを末梢側に向って挿入 することは，本症の静脈造影に必要な条件であ る.チューブが末梢側に向いていることにより， 注入された造影剂は一旦, 前腕の静脈に逆行性 に分布してから還流してくるので，上腕の静脈 系をきわめて自然の形で造影することができ， 頭静脈欠損を正確に診断しうる（図 2,3 ).

正中静脈より中枢側に向ってチューブを挿入 し静脈造影を行うと，チューブの先端の位置に よっては貴静脈のみに造影剂が流れ，実際に頭 静脈があるのに造影されず，診断を誤る場合が ある。したがって末梢側に向って造影剤を注入 することが本症の診断にはぜひ必要である.

\section{V . 治療および予後}

本症に対してはもちろん，外科的な手術適応 はないが，上肢の静脈は還流を阻害しないこと が循環障害による症状を防ぐために必要である.

乳幼児期には「おぶいひも」でおぶうことは 極力避け，も乙やむをえ時は腋简になるべく 圧迫の加わら妨なな配慮をする.成長後も腋 營に圧迫の加わるような要因はできるかぎり避 ける必要がある.

上肢の静脈還流を阻害するような循環障害を くり返していると, 組織の変化をきたすことは 
当然であり，21例中の 5 例は母親が患側の手， および腕の太くなったことに気付いていた.

また少ないことではあるが, 静脈血のうっ滞 による静脈血栓形成，あるいは静脈拡張症をき たす可能性もありうる13).

長期予後についてはまだ明らかではないが， 「おぶいひも」でおぶうことをやめると，太かっ た患側上肢も次第に正常に復するものである.

したがって腋䆚静脈を圧迫するような要因を 避けるならば，予後はおおむね良好と考えられ る.

（擱筆に当り恩師市橋保雄教授の御校閲を深謝致し ます. )

\section{文献}

1）小佐野満：日本小児科学会誌，72；241，1968.
2) Osano, M. : VIII. International congress of angiology. Rio de Janeiro, Brasil, 1972.

3) Osano, M. : Am. J. Dis. Child, 118; 479, 1969.

4) Mc Murrich, C. P. : The development of the human body, 1904, 8) より引用.

5) Lewis, F.T. : Am. J. Anat., 5; 113, 1906.

6) Patten, R. M. : Human embryology. 2nd Ed. Blakiston Co., 1953.

7) Abramson, D. I. : Blood vessels and lymphatics. Academic Press, 1962.

8) Berry, R. J.A. : Anat. Anz., 33; 591, 1908.

9）岡本規矩男 : 慶応医学, 2; 1, 1922.

10）忽那将愛：解剖学会誌，2； 708，1929.

11）松木 清 : 朝鮮医会誌，23；1266，1933.

12) Allen, E. D. :Peripheral vascular diseases, 4th Ed, Saunders, 1972.
第 6 巻第 2 号 (1975年 6 月)

\section{<特集・頭部外傷後の植物人間 $>$}

初期臨床像からみた頭部外傷後の植物化…南 卓 男・他 “植物症”の定義と分類.. 太田 富 雄・他 頭部外傷後の植物人間の臨床像と検查成績

頭部外傷後植物状態を呈した症例の検討 玉 王 紀 彦・他 鈴 木 陽 一・他 治療面よりみた植物状態——特に

$\mathrm{NPH}$ 病態よりみた検討 …….........京 井 喜久男 - 他 